\title{
Erratum to: The C-reactive protein level after total knee arthroplasty is gender specific
}

\author{
Christoph Windisch ${ }^{1}$ (D) Steffen Brodt ${ }^{1} \cdot$ Eric Roehner $^{1} \cdot$ Georg Matziolis $^{1}$
}

Published online: 1 March 2017

(C) European Society of Sports Traumatology, Knee Surgery, Arthroscopy (ESSKA) 2017

Erratum to: Knee Surg Sports Traumatol

Arthrosc (2016) 24:3163-3167

DOI 10.1007/s00167-016-4289-5

The original version of this article unfortunately contained a mistake. The affiliation details of the authors are incorrect. The correct affiliation is:

Orthopaedic Department, Jena University Hospital, Campus Eisenberg, Klosterlausnitzer Straße 81, 07607 Eisenberg, Germany.

The online version of the original article can be found under doi:10.1007/s00167-016-4289-5.

Christoph Windisch

c.windisch@krankenhaus-eisenberg.de

Steffen Brodt

s.brodt@krankenhaus-eisenberg.de

Eric Roehner

e.roehner@krankenhaus-eisenberg.de

Georg Matziolis

g.matziolis@krankenhaus-eisenberg.de

1 Orthopaedic Department, Jena University Hospital, Campus

Eisenberg, Klosterlausnitzer Straße 81, 07607 Eisenberg,

Germany 